\title{
Principle-guided Policy Experimentation in China: From Rural Tax and Fee Reform to Hu and Wen's Abolition of Agricultural Tax
}

\author{
Guohui Wang *
}

\begin{abstract}
The abolition of Agricultural Tax in 2005 was a major policy of the early $\mathrm{Hu}-$ Wen administration. But how and why did it happen? Drawing on abundant media reports, archive documents and internal speeches by key policymakers, as well as on the author's interviews, this article argues that this reform was pushed through (the "how") by "principle-guided policy experimentation" with origins in the period of Jiang Zemin's leadership. Not only does this show policy continuities from the Jiang-Zhu era into the $\mathrm{Hu}-$ Wen period, it also reveals a different process of policy experimentation from that identified by Sebastian Heilmann in the economic policy arena. Under principle-guided policy experimentation, Chinese central decision makers first reached consensus on the principle of the Rural Tax and Fee Reform (RTFR) drawing on policy learning from prior bottom-up local experimentation, and then formulated and implemented an experimental programme from the top-down, funding it in order to encourage local governments to participate. The evidence suggests that international, political (rural instability), economic and fiscal considerations came to explain leaders' decisions (the "why") on tax reform as much as their individual preferences.
\end{abstract}

Keywords: policy experimentation; central-local relations; social reform; rural tax and fee reform

In December 2005, the Chinese central government under the leadership of $\mathrm{Hu}$ Jintao 胡锦涛 and Wen Jiabao 温家宝 formally announced the total abolition of Agricultural Tax. Over 145 billion yuan that was directly extracted from farmers every year was cut. From 2000 to 2010, the Chinese central government transferred over 570 billion yuan to local governments, subsidizing their revenue loss for carrying out the reform. ${ }^{1}$ This is considered by the Chinese official

* Department of China Studies, Xi'an Jiaotong-Liverpool University. Email: guohui.wang@xjtlu.edu.cn.

1 Xiao 2011, 8. 
propaganda as one of the great political achievements completed under the $\mathrm{Hu}-$ Wen leadership. How and why did this happen? Thanks to abundant attention paid to rural tax and fee reform (nongcun shuifei gaige 农村税费改革) in the past, we have learned much about the processes, contents, consequences and ramifications of this key reform. ${ }^{2}$ Drawing on the insights of existing literature, this article intends to trace the historical evolution of the complete policy process to identify key stages as well as critical actors and factors that shaped decisions leading to the abolition of Agricultural Tax.

Evidence shows that experimentation played a critical role from the beginning of this reform in early 1990s until its completion in 2005. However, as a social policy, ${ }^{3}$ rural tax and fee reform did not create obvious economic incentives or rent-seeking opportunities for local officials or social elites to initiate and implement it. This pattern of policy experimentation contrasts with what Sebastian Heilmann has identified in China's economic reforms. Heilmann suggests a staged process of policy change in China reflecting the unique central-local interactive model that he proposes as "experimentation under hierarchy."4 Largely emphasizing the bottom-up initiative of local actors, Heilmann confines his model to Chinese economic policy domains and rules out its applicability in generating transformative social policies. This is because, as he argues, social reforms cannot bring about short-term economic benefits and rent-seeking opportunities, which are indispensable to motivating local officials and social elites to engage in policy experimentation from the bottom-up. ${ }^{5}$ Examining political reforms initiated by local officials during the $\mathrm{Hu}-$ Wen period, Wen-Hsuan Tsai and Nicola Dean seem to affirm Heilmann's emphasis of the bottom-up initiative in policy experimentation, but they argue that local officials' initiative comes from gaining credits through "political performance" to get promotion under the cadre responsibility system. Wang Shaoguang, however, highlights the importance of the centre's top-down capacity in initiating policy experimentation. By examining the evolution of China's rural health funding system, Wang challenges Heilmann's view and argues that the Chinese Party-state can use experimentation to generate successful social reforms through policy learning and adaption. ${ }^{6}$ In a recent article, Ciqi Mei and Zhilin Liu, drawing on a case study of urban housing reform in China, argue that it was "conscious policy design" by the central government at the top rather than bottom-up policy experimentation that fundamentally caused the policy change. ${ }^{7}$ These scholarly divergences in understanding China's policy experimentation and the central-local interaction indicate the need for further exploration.

2 See, for example, Kennedy 2007; Li 2006b; Li 2006c; Li 2006a; Yep 2004.

3 Although this reform also has fiscal and economic ramifications, rural tax and fee reform is approached in this article as a social policy, because it aimed to tackle poverty, inequality and public goods provision issues among rural population in China.

4 Heilmann 2008, 9-12.

5 Ibid., 23.

6 Wang 2008.

7 Mei and Liu 2013. 
Drawing on an in-depth case study of the complete process of rural tax and fee reform and its evolution until the abolition of Agricultural Tax in 2005, this article attempts to continue Heilmann and other scholars' efforts in understanding China's experimentation-based policy process. In this article, the term "rural tax and fee reform" has two different meanings relating to two different stages of the reform. First, this term means different tax and fee reform programmes experimented with by some local governments bottom-up at the initiation stage from 1993 to 1999 . Second, this term also refers to the RTFR programme made and officially experimented with top-down by the central government from 2000 to 2005. From the perspective of policy process, this article takes rural tax and fee reform experimented with locally before 2000 as the early stage of the whole RTFR policy process.

Since this reform is taken as a great political achievement by the Chinese authorities, much "inside" information on the high-level decision-making process has been made public in recent years, enabling researchers to glimpse inside what is usually a "black box." These materials include key policymakers' internal speeches, press interviews and articles by high-level officials involved in central and local policymaking. ${ }^{8}$ All these valuable materials, combined with my interviews with government officials and policy researchers in Chinese official think tanks, ${ }^{9}$ enable an in-depth analysis of the policymaking process.

In the following sections, this article first summarizes Heilmann's policy model of "experimentation under hierarchy" and presents a refined experimentationbased policy cycle on the ground of the findings of the RTFR case. It then closely analyses the empirical evidence available on the policy process of RTFR and provides a stage by stage analysis, demonstrating how policy continuities finally led to $\mathrm{Hu}-W e n$ 's abolition of the Agricultural Tax. Finally, the article discusses the policy pattern of "principle-guided experimentation" in generating social reforms, and concludes by showing its potential explanatory power for China's social policy changes in the 21 st century.

\section{Policy Experimentation in China: A Theoretical Model}

Sebastian Heilmann pioneered a model of China's reform-era experimentationbased policy process, which he refers to as "experimentation under hierarchy." 10 In his model, experimental programmes are usually initiated by local officials who need to tackle pressing local issues and are largely motivated to pursue personal interests, though they may usually need support and protection from some

8 On the tenth anniversary of RTFR, a few key policymakers involved in this reform published articles recalling details of the policy process in 2011. Former Premier Zhu Rongji also published his internal speeches in recent years. See Zhu 2011.

9 I conducted a total of 12 interviews from September 2014 to April 2016. Five of the interviewees were government officials, four were policy researchers of central think-tank institutions and three were university scholars.

10 Heilmann 2008, 10. 
individual high-ranking officials. If positive results are produced from local experiments and more top-level decision makers support the policy innovation, a national experimental programme is likely to be formulated and implemented "from points to surface." With further expansion of the experimental programme, a new national law or regulation will be drafted through interministerial review. Then the new law will be passed by decision makers at the apex and can finally be implemented nationwide.

Heilmann's model, emphasizing the bottom-up initiative in policy experimentation, was largely drawn from policy cases in Chinese economic reform domains. He suggested that the model has obvious limits in generating social policies that cannot benefit the short-term economic interests of most local elites. ${ }^{11}$ Drawing on a case study of RTFR, a policy aimed at reducing the "farmers' burden" (nongmin fudan 农民负担) that had little direct benefit for local officials, this article shows how, in fact, experimentation did play an important role, but as part of a rather different process, one I characterize as "principle-guided policy experimentation."

The case of RTFR demonstrates that the policy cycle starts from a policy issue being identified by the state (Figure 1; stage I). Then local policy experimentation may be initiated by local policy entrepreneurs to tackle the pressing issue with encouragement and support from central policy entrepreneurs (Figure 1; stage II). The case of RTFR confirms other scholars' observation that informal patron-client relationships formed hierarchically between central and local policy entrepreneurs (as reflected by the dotted line in Figure 1) are critical for policy changes in China. ${ }^{12}$

With positive effects and growing influence, local policy experimentation may reach the responsible central decision-making agency. If the local experimentation can obtain the support and endorsement of the leader of the responsible central decision-making agency, it may indicate that the policy experimentation has moved onto the central decision-making agenda and is likely to be submitted to the apex of the political system (the Politburo Standing Committee or the Politburo) for discussion and approval (Figure 1; stage III). At this stage, the role of top leaders (especially the Party General Secretary) is vital. They may either give an active and stronger push to the policy or refrain from using their veto power to oppose it. The decisive sign of a policy proposal finally reaching consensus at the apex can be reflected in public speeches of the Party General Secretary or central documents (Figure 1; stage IV). At this stage, the consensus reached among top decision makers usually is on the principle and aim of the policy, and working out a detailed experimental programme is left to the next stage.

With consensus being reached and principle agreed at the apex, a specific interministerial working agency (usually in the form of a small central leading group) is established to work out a principle-guided experimental programme drawing

11 Ibid., 23.

12 Heilmann 2008; Chung 2000; Tsai and Dean 2014. 
Figure 1: The Experimentation-Based Social Policy Cycle

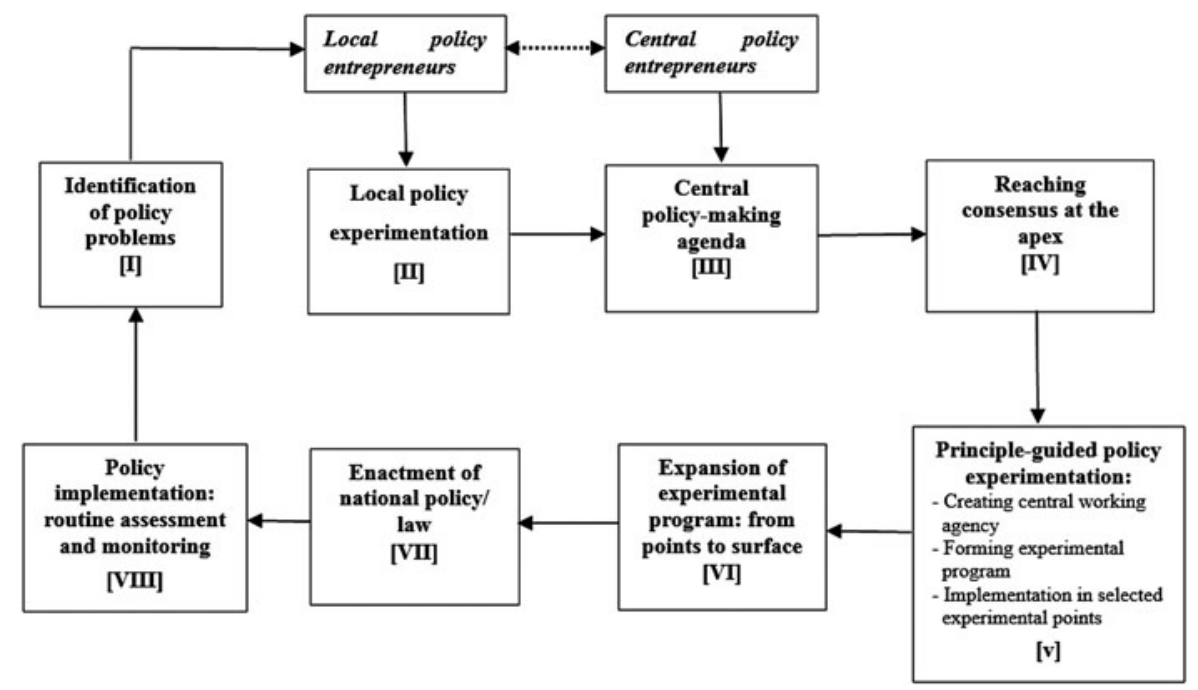

on experiences and lessons from prior local experimentation. Subsequently, the programme is carried out in selected experimental points top-down with central sponsorship if necessary (Figure 1; stage V). Based on results and experiences obtained in the selected experimental points, a decision to expand from "points to surface" may be made with a further push from the centre (Figure 1; stage VI). In the process of implementation, the experimental programme is further refined and finally leads to a new national policy/law (Figure 1; stage VII). Then routine policy assessment and monitoring (Figure 1; stage VIII) is carried out afterwards, which may initiate the next round of policy cycle.

This stage-based policy cycle drawn from the case of RTFR will be elaborated in the following sections. To some degree, empirical study of this case confirms Heilmann's analysis of China's staged process of policy experimentation, but there is also a critical difference. This policy process - "principle-guided policy experimentation" - demonstrates that the central decision makers first reach a formal consensus on principle of the reform. After reaching a consensus and agreeing in principle, a specific central inter-ministerial agency is established, a detailed experimental programme is worked out drawing on policy learning from prior local experiments, and then the programme is formally carried out in selected experimental points from the top-down. The experimentation expands from "points to surface" and eventually leads to policy change at the national level. This contrasts with Heilmann's model, in which local policy experimentation gradually grows from the bottom-up, expands from "points to surface," and then leads to a consensus at the apex and enactment of a new national policy. This principle-guided policy experimentation, as this article will discuss in its concluding section, may extend the applicability of "policy experimentation" to China's social policy domains. 


\section{Origin of the Rural Tax and Fee Reform (1988-1994): From the Farmers' Burden Issue to Local Policy Experiments [Stages I and II]}

\section{Evolution of the farmers' burden: identification of the policy issue [Stage I]}

Rural tax and fee reform originated from a policy proposal that in turn aimed to deal with the problem of farmers' burden. The farmers' burden turned into a prominent policy issue with the collapse of the commune system and implementation of the rural household contracting system in the late 1970s and early 1980s. ${ }^{13}$ Despite the centre's identification of the problem of farmers' burden in the mid-1980s, ${ }^{14}$ the issue had not been pressing until the late 1980s, thanks to the rapid development of the rural economy and increase in farmers' incomes. ${ }^{15}$

However, the serious slowdown in the rural economy from the late 1980s began to make the farmers' burden issue prominent again. ${ }^{16}$ In contrast to farmers' stagnant income growth, their burden of taxes and fees kept growing. This was largely because local governments, which were driven by demanding developmental goals, continued to expand their public spending. However, evergrowing government expenditure was ultimately transferred to the farmers and became their burden, something that led to an increase of rural violent mass incidents and tense state-farmer relations. ${ }^{17}$ As a result, farmers' burden remained a serious policy issue throughout the 1990s due to the centre's sustained urban industrial bias. ${ }^{18}$ It was against this background that local bottom-up experimentation with rural tax and fee ${ }^{19}$ reform emerged in Anhui in the early 1990s.

\section{Initiation of the local policy experimentation: policy entrepreneurs and policy innovation (Stage II)}

Consistent with Heilmann's findings, ${ }^{20}$ successful initiation of rural tax reform experiments was due to the joint efforts of both local and central policy entrepreneurs under the hierarchical structure. He Kaiyin 何开荫, a policy researcher in

13 Guojia shuiwu zongju nongshuiju keti zu 2000, 23-24.

14 CCCCP (Central Committee of the Chinese Communist Party) 1984; CCCCP and the State Council 1985.

15 Wen 2012, 94-101.

16 Wen 2012, 113; Chen 1992.

17 Chen 1992, 3; Wen 2012, 113 and 117; Li 2006c, 91-92.

18 Huang 2008.

19 In fact, "rural tax and fee" is a term as vague as "farmers' burden." By definition, "rural tax" refers to official taxes specifically targeting the rural population. Before RTFR was carried out in 2000, rural tax included Agricultural Tax (including an Agricultural Tax surcharge), Agriculture Special Products Tax and Slaughter Tax. After RTFR, Slaughter Tax and Agricultural Special Products Tax were abolished nationwide by the central government in 2000 and 2004 respectively. The term "rural fees" refers to numerous fees, charges and levies that were collected from farmers before RTFR and were approved by both central and local governments. Only certain kinds of charges and levies were approved by the central government and were legally based, such as three village levies and five township charges. Most of the rest were imposed upon farmers by local governments and their agencies as administrative fees. Before RTFR, these rural taxes and fees were usually collected by township and village officials directly from farmers even without clear differentiation. See Li 2006a and Yep 2004. 
Anhui provincial government, has been referred to as "the first person of rural tax and fee reform” (nongcun shuifei gaige diyi ren 农村税费改革第一人). As early as 1988, before even the leadership of Jiang Zemin 江泽民, He Kaiyin was invited by Wang Yuzhao 王郁昭, then deputy director of the Central Rural Policy Research Office (CRPRO) (Zhongyang nongcun zhengce yanjiushi 中央农村政策研究室), to submit a policy research report for a high-level conference organized by the CRPRO. ${ }^{21}$ According to his investigation in rural Anhui, He submitted to the conference a policy research report, in which he suggested reducing farmers' burden by initiating rural tax and fee reform. Later He's policy proposal was referred to the central decision-making level. ${ }^{22}$ In 1991, He Kaiyin received a message that then Premier Li Peng 李鹏 encouraged him to work out a feasible policy proposal and try to experiment with it at local level to gain experience. ${ }^{23} \mathrm{He}$ Kaiyin's policy proposal also received support and encouragement from the most influential rural policy expert within the Party, then head of the CRPRO, Du Runsheng 杜润生. In spring 1992, Du introduced He to then Fuyang prefecture (in Anhui province) Party secretary, Wang Zhaoyao 王昭耀, who would support experimentation of rural tax and fee reform in his jurisdiction. ${ }^{24}$

With active promotion of both the local and central policy entrepreneurs, experiments of rural tax and fee reform first took place in Fuyang 阜阳 prefecture, Anhui province. From 1993 to 1994, local experiments began to sprout in some counties of Fuyang, with support and approval from leaders of both Fuyang and the Anhui provincial government. ${ }^{25}$ In the same period (19931994), rural tax and fee reforms were also adopted and experimented with on a small scale by local governments in other provinces. These local experiments in different places had been under close observation by responsible agencies and officials of the central government. ${ }^{26}$

\section{Endorsement from Key Central Decision maker and Getting onto the Central Policymaking Agenda (1994-1997) [Stage III]}

With reportedly positive results produced from the local experiments, Jiang Chunyun 姜春云, then vice-premier and head of the Central Rural Work Leading Group (CRWLG) (Zhongyang nongcun gongzuo lingdao xiaozu 中央 农村工作领导小组), paid an official inspection to Fuyang in December 1994. Jiang Chunyun explicitly backed the experimentation and gave his support and affirmation to the reform. ${ }^{27}$

21 The CRPRO was the Party's rural policy research agency affiliated to the Secretariat of the CCCCP in 1980s. The CRPRO was dismissed in 1989.

22 Wang, Wang and Zhang 2001; Du and Liu 2001.

23 Wang, Wang and Zhang 2001, 7; also see Chen and Chun 2004, 269-272.

24 Zhang 2000, 9.

25 See Ma 1995; He 1995; Liu and Du 2002, 11-12; Pan 2008, 26.

26 Li 1995, 38-39.

27 Pan 2008, 26; Du and Liu 2001. 
Due to Jiang Chunyun's political status as the highest central decision maker in charge of rural work, his endorsement meant that Anhui's experimentation leapt onto the central government decision-making agenda. ${ }^{28}$ As a result, from 1995 to 1997, rural tax and fee reform had remained high on the central policy agenda and local experiments had gained serious attention and consideration at the central decision-making level. ${ }^{29}$ In December 1996, the centre issued a document, stating "the explorations of tax and fee reform carried out in some major grain production districts may continue to be experimented." 30 This is the first time that local experimentation on rural tax and fee reform was affirmed by the centre in its official document.

Although "reducing farmers' burden" had been repeatedly emphasized by the centre during this period, the consensus required to carry out rural tax and fee reform at the national level was not reached at the apex of government largely due to concerns about the state fiscal capacity. Both local experimenters and central decision makers were aware that rural tax and fee reform, while reducing farmers' burden, would lead to further decrease of local government revenue, which had already depreciated because of the 1994 tax-share reform. ${ }^{31}$ In other words, the central decision makers were hesitant to cut farmers' burden while leaving local governments with a serious funding gap. ${ }^{32}$

\section{Reaching Consensus at the Apex in 1998 [Stage IV]}

The consensus on reducing farmers' burden through rural tax and fee reform was finally reached at the state-state apex in 1998. On 25 September 1998, Jiang Zemin gave an important public speech in Anhui in memory of the 20th anniversary of the initiation of rural reform, declaring that rural tax and fee reform should be one of the most crucial issues to be tackled. ${ }^{33}$ The supreme leader's public declaration on carrying out rural tax and fee reform clearly signalled the top leadership's consensus. Three weeks after Jiang Zemin's speech, this consensus was formally confirmed in Decision on the Crucial Issues Concerning the Agricultural and Rural Work passed by the Central Committee of the Chinese Communist Party (CCCCP) on 14 October 1998. ${ }^{34}$

Why did the centre suddenly reach consensus on adopting rural tax and fee reform in 1998? The most important and direct factor was the external shock caused by the Asian Financial Crisis (AFC), which erupted in July 1997 and by 1998 had begun to have a serious impact on China's export-driven economy entrenched from the early 1990s. China's export-driven economic growth plus

29 Zhao 1995; Chen and Chun 2004, 336-39.

30 CCCCP and the State Council 1997, 568.

31 For the effects of the 1994 tax-share reform to local government finance, see Yep 2008.

32 Xiang 2011, 12.

33 Jiang 1998, 5.

34 CCCCP 1998, 9. 
urban-oriented reform in the 1990s was at the cost of shrinking domestic demand and declining rural development. ${ }^{35}$ In tackling the domestic economic crisis triggered by the AFC, the Jiang-Zhu leadership was convinced of the importance of stimulating domestic demand and rebalancing rural-urban development. From early 1998, top leaders repeatedly emphasized "expanding domestic demand" and "exerting the potential of domestic market," 36 phrases that then appeared in official discourses. ${ }^{37}$ As stimulating domestic demand became the CCP's long-term national strategy, increasing farmers' income became a pressing issue concerning China's overall national development. However, because farmers' income growth also significantly slowed down in the face of the economic recession after 1997 , reducing farmers' burden became the only feasible option for the centre. This unexpected external shock largely explains why the central decision makers suddenly reached consensus over rebalancing rural-urban development and agreed the principle of reducing farmers' burden by adopting tax and fee reform in 1998. ${ }^{38}$

If the AFC was the direct factor that pushed the Jiang-Zhu leadership to reach consensus, tax-sharing system reform was a critical structural factor that compelled the central government to adopt tax and fee reform. With the centre's tax-sharing reform implemented in 1994, the fiscal capacity of local governments (especially at the lowest township level) fell significantly, but at the same time they had to take on heavier responsibilities in public goods provision. Local governments, especially county and township governments in underdeveloped agricultural areas, therefore had to rely more on extracting revenue from the farmers for government operation and public goods provision. Local governments' revenue extraction not only caused farmers' burden to increase, but also led to tense state-farmer relationships and serious rural unrest despite the centre's efforts to control farmers' burden. ${ }^{39}$ After 1997, as farmers' income growth slowed down, rural instability became a more pressing problem and stimulated central decision makers to seek a fundamental solution to the issue of farmers' burden.

\section{RTFR: Principle-guided Policy Experimentation (1998-2001) [Stage V]}

\section{Creating a central working agency}

Only five days after Jiang Zemin's public speech in Anhui indicating the centre's consensus on carrying out rural tax and fee reform, an inter-ministerial agency called the "RTFR ${ }^{40}$ Work Group of the State Council" (Guowuyuan nongcun

35 Wen 2012, 106-138.

36 Qi 2009, 37.

37 CCCCP 1998, 2

38 Duckett and Wang 2017, 98.

39 The local fiscal difficulty after the tax-share system was implemented in 1994 has been analyzed in detail by Yep (2004).

40 From this stage (stage V), RTFR is used as a proper noun abbreviation, referring to the top-down experimentation carried out by the centre, which is different to the term "rural tax and fee reform" experimented locally from the bottom-up. 
shuifei gaige gongzuo xiaozu 国务院农村税费改革工作小组) was established at the central level. This work group was also informally called a "three-person-group" (sanren xiaozu 三人小组), and consisted of Xiang Huaicheng 项怀诚 (the Minister of Finance), Chen Yaobang 陈耀邦 (the Minister of Agriculture) and Duan Yingbi 段应碧 (the director of the Office of CRWLG), with Xiang Huaicheng taking the lead. A few months later, the "Office of RTFR Work Group of the State Council," consisting of staff from relevant ministerial agencies, was also formally created and began to function. ${ }^{41}$

\section{Forming an experimental programme at the central level}

Following the creation of the inter-ministerial RTFR work group, an experimental programme embodying the central leadership's consensus and principle was meant to be worked out. Xiang Huaicheng, head of the three-person group, revealed the top leaders' directives to his work group in the process of policy formation. Jiang Zemin's directive was: "RTFR concerns 900 million farmers' personal interests. The direction of the reform is correct. This important issue must be done properly." Zhu Rongji 朱F基 underlined the same principle by saying: "The reform must be able to truly reduce farmers' burden. It would better remain unchanged than simply put old wine in new bottles." Wen Jiabao, then vicepremier in charge of rural work, gave his instruction: "The first and foremost aim of RTFR is to reduce farmers' burden. Meanwhile, local fiscal capacity should also be considered. It is necessary to concern fiscal balance, but we should not only care about fiscal balance. We must put (reducing) farmers' burden first." 42

The process of working out the experimental programme was not completely dominated by the centre, but was a principle-guided central-local interaction based on consultation, bargaining and policy learning of the previous local experiments. The major theme of increasing the Agricultural Tax rate but cancelling all other fees and charges that had been experimented with locally was adopted in the centre-sponsored RTFR programme. The most difficult bargaining in the process of policy formation was how to set the new Agricultural Tax rate. Taking into consideration that the actual rate of Agricultural Tax was 2.5 per cent in 1997, the work group initially suggested a 5 per cent Agricultural Tax with a 10 per cent surcharge of the amount of the Agricultural Tax (to substitute the township charges and village levies). ${ }^{43}$ This rate was based on the work group's calculation of farmers' legal taxes and fees. This proposed rate however was strongly opposed by local governments, who worried about their loss of revenue. Consequently, a compromise rate of 7 per cent Agricultural Tax plus a 20 per cent ${ }^{44}$

41 Xiao 2011, 9.

42 Xiang 2011, 13

43 So the original proposed Agricultural Tax rate plus surcharge was 5.5 per cent.

4420 per cent surcharge of the 7 per cent Agricultural Tax equals 1.4 per cent increase. Namely, the Agricultural Tax rate plus surcharge was 8.4 per cent. 
surcharge of the amount of the agricultural tax was finally settled in the RTFR programme. $^{45}$

It took around one and a half years for the centre to devise an experimental programme - from September 1998 to March 2000, when the centre officially issued its Circular on Carrying out RTFR. The unveiled RTFR programme demonstrated that policy learning drawn from local experiments and experiences in the previous years were indispensable for the formation of the central programme. The stipulations in the RTFR programme, such as reducing farmers' burden by increasing Agricultural Tax rate but cancelling all other fees, abolishing Slaughter Tax, standardizing Agricultural Special Products Tax, gradually abolishing farmers' labour obligations and so on, were all drawn from previous local experiments. ${ }^{46}$

\section{The principle-guided policy experimentation in Anhui}

Due to the complexity and importance of the reform, the strategy of "from points to surface" was adopted by the centre to minimize risk and accumulate experience. When determining which provinces to choose as experimental points, the work group's original plan was to choose six provinces with two in the east, middle and west region respectively. But when the draft RTFR programme was released for consultation from local governments, those provinces that had expressed their intention to participate in the reform as experimental points withdrew one by one. This was because the centre had not agreed to make fiscal transfers to provinces carrying out RTFR in order to compensate their revenue loss, which had perhaps been expected by these provinces. Instead, the centre expected local governments to absorb the revenue reduction themselves by cutting local expenditure and downsizing local administration. ${ }^{47}$ In view of local governments' revenue shortage after the 1994 tax-share reform, it was a rational choice for those provinces to withdraw. In the end, only Anhui province decided to carry out the RTFR programme. ${ }^{48}$

Then why did Anhui decide to implement RTFR while other provinces withdrew? First, the key leader, then Party secretary of Anhui province, Hui Liangyu 回良玉, had acted as the key policy entrepreneur of rural tax and fee reform in Anhui from 1994, when he was the governor of Anhui province. Since he supported and nurtured the reform from the bottom-up in the very beginning, he was likely to welcome RTFR. Although the experimentation with RTFR in Anhui which officially started in March 2000 was not under his leadership, the decision to implement RTFR in Anhui was made by Hui before he was transferred to Jiangsu province in December $1999 .{ }^{49}$ Second, since rural tax and fee

45 Liu 2003, 8.

46 For the detailed analysis of the RTFR programme see Yep (2004) and Li (2006a).

47 Xiao 2011, 12.

48 Pan 2008, 28.

49 Hui Liangyu was transferred from the position of Party secretary of Anhui to Party secretary of Jiangsu province in December 1999 just before Anhui made the decision to experiment RTFR. See Xiao 2011, 12. 
reform originated in Anhui and had been locally experimented with from the early 1990s, Anhui therefore had accumulated more experience and advantages in carrying out the reform than other provinces. Third, as the province where major rural reform was initiated in the late 1970s, Anhui had a reputation for breakthroughs and courageous explorations in reform. Fourth, as a major agricultural province, the issue of the farmers' burden had long been a pressing issue. In addition to the four reasons, evidence also indicates that Anhui provincial leaders had some confidence that the centre would provide necessary sponsorship should the experimentation go wrong..$^{50}$

In March 2000, the centre issued its Circular on Carrying out RTFR, and Anhui was the only provincial experimental point to carry out the reform from April 2000. As far as the principle of reducing farmers' burden was concerned, the reform had been successfully implemented in Anhui in the first year of experimentation. According to Anhui province statistics, a total of 1.84 billion yuan in farmers' burden was cut in the first year, equivalent to a 30-40 per cent income drop for each township and village administration. ${ }^{51}$ At the same time, local governments and public employees (local officials, village cadres and rural school teachers) in Anhui, at the township and village level in particular, became losers in the reform owing to serious revenue loss. Local government operations, salary payments for rural school teachers and village cadres, as well as public goods provision were all in difficulty. ${ }^{52}$ To match the local government revenue shortfall caused by RTFR, a large-scale administrative downsizing was carried out at the township and village level. Mergers of township governments, villages and schools were evident and a significant number of township and village cadres and rural school teachers were laid off. ${ }^{53}$

Why was the experimental policy that was largely unwanted by local elites implemented so efficiently and able to successfully achieve the principle of reducing farmers' burdens? Effective top-down mobilization based on the cadre responsibility system was a key reason. ${ }^{54}$ Once carrying out the reform programme became the centre's firm decision after consensus building at the apex, top-down mobilization was used to overcome resistance and achieve the desired policy goal. Xiang Huaicheng revealed a decade later that the principle and major contents of RTFR were "all decided by the centre" and "because the reform concerned the overall situation of development, reform and stability of our country, it had to succeed and could not afford to fail." ${ }^{55}$ In other words, it was the centre's strong determination to reduce farmers' burden and readjust the distributive relationship between farmers and the state that largely ensured RTFR was implemented. ${ }^{56}$

50 Chen and Chun 2004, 360; Pan 2008, 28.

51 For details, see Yep 2004, 50-54.

52 Yep 2004, 55; also see $\mathrm{Li}$ and $\mathrm{Wu} 2005$.

53 Yep 2004, 50-54.

54 Pan 2008, 30.

55 Xiang 2011, 13.

56 For how the top-down cadre responsibility system facilitated RTFR implementation in Hubei province, see Li 2006c, 100-102. 
In addition to top-down mobilization, the centre also realized from Anhui's experimentation that central transfer payments were necessary to make the reform sustainable and to remove disincentives from local officials and elites. Six months after Anhui began implementing the reform, in October 2000, the centre decided to make fiscal transfer to Anhui to compensate for its major revenue loss as a result of carrying out the experimentation. In 2000 and 2001, the centre transferred 1.1 billion and 1.7 billion yuan respectively to Anhui as special transfer payments supporting its RTFR experimentation. ${ }^{57}$

As the very aim of policy experimentation is to identify problems and avoid potential risks so as to accumulate experience for further expansion, experiment in Anhui did make the long-term hidden problem rise to the surface: the serious shortage of government funding in rural public goods provision that had long relied on farmers' direct contribution. Even though the centre also shared the cost by making transfer payments to Anhui, the sum transferred could not fully compensate for the revenue gap caused by the reform. The result from Anhui's experimentation also illustrated that the centre's original estimate of a 20 billion yuan transfer payment for nationwide implementation had been far from enough. ${ }^{58}$ This unexpected situation made the central government, which had been in serious fiscal deficit since the AFC, put a "sudden brake" on the policy in April $2001^{59}$ and drop its original intention to expand the reform to more provinces. ${ }^{60}$

\section{Expansion of RTFR from "Points to Surface" [Stage VI]}

\section{Expansion of RTFR in the later period of the Jiang-Zhu era (2001-2002)}

Despite the centre's sudden brake in 2001, Jiangsu province took the initiative to become the second provincial experimental point to implement RTFR through self-funding. Jiangsu would absorb its local revenue loss using its own fiscal capacity without relying on the centre's transfer payment. It is important to note that the Party secretary of Jiangsu province at that time was Hui Liangyu again, the key local policy entrepreneur who had strongly supported and promoted Anhui's initial local experiments on rural tax and fee reform since the mid-1990s.

In March 2002, the final year of the Jiang-Zhu leadership, the centre issued Circular on the Work of Expanding RTFR Experimental Points. Thanks to continual growth in the state fiscal capacity and the centre's fiscal sponsorship, ${ }^{61}$ RTFR provincial-level experimental points rapidly expanded to 20 provinces in that year. Another important factor that made the centre expand the reform so

57 Chang 2003, 14.

58 Ibid., 14. In April 2001, provinces submitted their calculation on the fiscal gap for implementing RTFR to the centre, and the total figure amounted to 100 billion yuan, which was outside the centre's original expectation. See Li 2006c, 99.

59 See Li 2006c, 97-99.

60 State Council 2001.

61 The central transfer payment for RTFR was 24.5 billion, 30.5 billion, 52.4 billion in 2002, 2003 and 2004 respectively. See Li 2006c, 100. 
quickly was China's joining the WTO in 2001, which according to the centre's judgement could well have a negative influence on China's agriculture and farmers' income growth. Once again, a central document issued in January 2002 for expanding RTFR reiterated the reform's importance for the national economy, saying 'increasing farmers' income is not only concerned with the development of rural economy, improvement of farmers' life and rural stability, but also concerned with carrying out the policy of expanding domestic demand and the whole national economy." 62

\section{Nationwide expansion of RTFR at the beginning of the Hu-Wen era (2003)}

In the 16th CCP National Congress held in late 2002, when Hu Jingtao and Wen Jiabao took over central leadership, the CCP officially raised the core idea of "building a well-off society in an all-around way" and reiterated the importance of "overall planning for urban and rural socioeconomic development" and "increasing farmer income." 63 The Central Rural Work Conference held in January 2003 specified that "from now on, the increased funding for education, healthcare and culture will be mainly used in the countryside so as to gradually reduce the gap between urban and rural social development." ${ }^{64}$ In particular, since Wen Jiabao had been (as head of CRWLG and vice-premier) the key central decision maker in charge of rural work for many years before becoming premier, he was considered a pro-rural premier compared with his predecessor Zhu Rongji. ${ }^{65}$ In addition, Hui Liangyu, the most critical local leader and policy entrepreneur supporting RTFR, was promoted to the position of vice-premier and head of the CRWLG in charge of rural work in 2003 (where he remained for the entire Hu-Wen administration until 2013). Drawing pro-rural leaders into the highest decision-making level not only guaranteed policy continuities but also reflected the centre's consensus over a pro-rural policy shift, which had already crystallized in the late Jiang-Zhu era.

In his first press conference as premier, Wen Jiabao declared that the primary challenge of his new administration was "lagging agricultural development and the slow growth of farmers' income that have become an important factor constraining expansion of domestic demand," 66 an issue that had been repeatedly emphasized by the Jiang-Zhu leadership since 1998. While promising to further strengthen fiscal support to the countryside, Wen, in the same press conference, publicly indicated that the ultimate aim of RTFR was "to cut all taxes and fees that should not be paid by farmers." ${ }^{\prime 67}$ The incoming Hu-Wen leadership's pro-

62 CCCCP and the State Council 2002, 1.

63 Jiang 2002, 9.

64 Sun 2003, 1.

65 Interview with a senior policy researcher in the Development Research Centre of the State Council, 11 October 2015.

66 Wen 2003, 26.

67 Ibid., 29. 
rural policy orientation was translated into a series of economic and social policies aiming to speed up rural development.

The Hu-Wen leadership's commitment to the pro-rural principle was also underpinned by a robust economic growth from 2003 to 2007. On the one hand, the Chinese economy had recovered from the serious recession caused by the AFC; on the other hand, China's joining WTO in 2001 had also greatly contributed to its export-driven economic growth. In addition, government investment in rural infrastructure construction and social welfare projects not only absorbed excess production capacity but also served to expand domestic demand. ${ }^{68}$

Against this policy background, the centre quickly expanded RTFR throughout the country in 2003, with increased central transfer payment to subsidize local governments' revenue loss. Despite its nationwide implementation, the centre did not intend to enact a new national law, but still officially referred to the reform as "experimental" because, according to then director of the Office of CRWLG, the reform was still regarded as being immature and inconclusive by the centre at that time, and therefore needed to be further strengthened and improved before formal enactment of a new system or national law. ${ }^{69}$

\section{From Nationwide Implementation of RTFR to Abolition of Agricultural Tax in the Early Hu-Wen period (2004-2005) [Stage VII]}

After nationwide implementation of RTFR in 2003, the $\mathrm{Hu}-\mathrm{Wen}$ leadership gave a further push to abolishing Agricultural Tax in 2004 as part of the centre's larger plan to improve farmers' income and subsidize agriculture. ${ }^{70}$ In the No. 1 Central Document of 2004, the centre demanded that Agriculture Special Product Tax be abolished from 2004, that the Agricultural Tax rate be reduced by 1 per cent, and that areas with "mature" conditions may further reduce or abolish Agricultural Tax. On 5 March 2004, at the Second Session of the 10th National People's Congress, Wen Jiabao officially announced in his government work report the goal of "abolishing Agricultural Tax in five years." 71 Local governments responded to the centre's announcement quickly. In 2004, Heilongjiang and Jilin province were the first to abolish Agricultural Tax as provincial experimental points. At the same time, Agricultural Tax in other provinces was required by the centre to be reduced by 3 per cent in 11 provinces and by 1 per cent in the rest (Agricultural Tax Surcharge was also lowered or abolished accordingly). By the end of 2004, Beijing, Shanghai, Tianjin, Zhejiang and Fujian province had abolished Agricultural Tax. ${ }^{72}$

In 2005, the reform was even further accelerated. By the end of the year, the provinces that abolished Agricultural Tax were quickly expanded to 28, with

68 Wen 2012, 187-217.

69 Liu 2003, 9.

70 Li 2006a, 159-160.

71 Wen 2004.

72 Li 2005. 
only 220 counties in Hebei, Shandong and Yunnan provinces temporarily retaining Agricultural Tax, though with a rate of less than 2 per cent. ${ }^{73}$ Local governments' unexpected acceleration made it possible for the centre to formally abolish Agricultural Tax three years ahead of the original schedule. On 29 December 2005, the Standing Committee of the 10th Session of the National People's Congress passed a resolution to repeal the Agricultural Tax Statute. ${ }^{74}$

\section{Conclusion}

It has been widely acknowledged that one of the major legacies of the Hu-Wen administration is its strategic shift from the Jiang-Zhu administration's urban and market-oriented reform to a "pro-rural" and social-oriented reform. Abolition of Agricultural Tax is claimed by the Chinese official propaganda as one of the key social programmes that earned much credit for the $\mathrm{Hu}-$ Wen leadership. However, the longitudinal examination of the process of RTFR has highlighted the importance of policy continuities between the Jiang-Zhu leadership and the $\mathrm{Hu}-$ Wen leadership. As demonstrated above, soon after succeeding the Jiang-Zhu leadership in late 2002, the $\mathrm{Hu}-\mathrm{Wen}$ leadership vigorously pushed through and swiftly expanded RTFR (Stage VI) until the abolition of Agricultural Tax (Stage VII) in 2005. However, it is worth noting that it was the Jiang-Zhu leadership that reached consensus and agreed the principle of carrying out RTFR (Stage IV) in 1998, and subsequently implemented the principleguided experimentation with great effort (Stage V) until it passed the "relay baton" to the Hu-Wen leadership in 2002.

The Hu-Wen leadership continued RTFR and quickly completed it early in their first term. This was possible not just because of the booming economy during that period. Rather, growth of both the economy and state fiscal capacity combined with the centre's determination to balance rural-urban development to facilitate the Party-state's rural-oriented policy shift. This article therefore argues that policy divergence caused by top leadership change may have been largely overestimated in China' reform era. International, political, economic and fiscal considerations affected the timing of central decision-making as much as individual leaders' preferences.

The RTFR policy process examined by this article does not reject Heilmann's experimentation-based policy model. Instead, the concept of "principle-guided policy experimentation" suggested by this article attempts to show how policy experimentation works in China's social reform domains, where local governments do not have economic incentives to experiment. Heilmann explicitly excluded social reforms from his policy experimentation model, apparently because he emphasized the bottom-up initiative of local actors when articulating his concept of "policy-experimentation under hierarchy." $\mathrm{He}$ argues that

73 Nongcun zonghe gaige bangongshi (The Office of Rural Comprehensive Reform) 2008, 13.

74 Pang 2012, 25. 
"experimental programs that do not immediately benefit the interest of local elites have a very slim chance of success."75

This article argues that experimental programmes pushed through by the centre and implemented from top-down constitute another policy experimentation model. The "principle-guided policy experimentation" model proposed by this article highlights the centre's strong capacity, underpinned by the cadre responsibility system and fiscal power, to coordinate and implement reforms that may go against local officials and elites' interests. The process of RTFR shows that consensus and principle reached at the apex of the Chinese political system were a prerequisite for the subsequent top-down policy experimentation that finally led to nationwide policy change.

Policy experimentation of this type may help us to further understand the transformation of social policies in China in the first decade of the 21st century and beyond. Compared with Chinese economic reforms, social reforms in present-day China may be subject to more substantial divergence of opinion on imperatives, priorities, parameters and approaches of the reform among Chinese policymakers of various levels. Social reforms largely concern the redistribution of resources among different segments of the population and it is therefore difficult to stimulate bottom-up experimentation. Policy experimentation in Chinese social domains clearly needs the strong capacity of the central Party-state and its leaders, prior consensus building on basic principles and directions among top decision makers and even stronger top-down administrative and fiscal capacity to adapt the Chinese governing system for future challenges.

\section{Acknowledgement}

The author would like to thank Jane Duckett, Yu Keping, Jude Howell, David Goodman and two anonymous reviewers for their helpful comments. The China Postdoctoral Science Foundation and the United Kingdom's Economic and Social Research Council supported research for this article through grants 2015M581136, ES/J012629/1 and ES/J012688/1.

\section{Biographical note}

Guohui WANG is associate professor in the department of China studies at Xi'an Jiaotong-Liverpool University. He mainly researches rural governance and public policy in China.

摘要: 2005 年废除农业税是胡温执政前期实施的一项重大社会改革。这项 改革究竟是怎样实施的, 为什么会实施这样的改革? 本文把这项发端于江 泽民时代的农村税费改革的政策过程概括为“原则性政策试验”, 认为这项 
改革不仅凸显了胡温和江朱时代中央政策的延续性, 同时还揭示出一种与 韩博天在中国经济改革领域所发现的政策试验过程不同的模式。原则性政 策试验显示, 中央最高决策层在前期地方性改革试点的基础上, 首先对实 施农村税费改革的基本原则达成共识, 然后由中央自上而下地设计和推行 试点方案, 由点到面, 最终形成全国性的政策。证据还表明, 国际因素、 政治因素（农村稳定）、财政经济因素, 以及领导人的个人偏好都对中央 决策层实施这项改革起到关键作用。

关键词: 政策试验; 央地关系; 社会改革; 农村税费改革

\section{References}

CCCCP. 1984. "Guanyu 1984 nian nongcun gongzuo de tongzhi" (Circular on the rural work in 1984), China.com.cn, 8 April 2008, http://www.china.com.cn/aboutchina/data/zgncggkf30n/ 2008-04/09/content_14685167.htm. Accessed 15 May 2016.

CCCCP and the State Council. 1985. "Zhonggong zhongyang guowuyuan guanyu zhizhi xiang nongmin luanpaikuan luanshoufei de tongzhi" (Circular on stopping imposing unauthorized charges and levies upon farmers), People.cn, http://www.people.com.cn/item/flfgk/gwyfg/1985/ 112401198503.html. Accessed 10 May 2016.

CCCCP. 1998. "Guanyu nongye he nongcun gongzuo ruogan zhongda wenti de jueding" (Decision on a number of critical issues concerning the agricultural and rural work). Qiushi 21, 2-12.

CCCCP and the State Council. 1997. "Guanyu qieshi zuohao jianqing nongmin fudan gongzuo de jueding" (Decision on effectively carrying out the work of reducing farmers' burden). Zhonghua renmin gongheguo guowuyuan gongbao 12, 563-68.

CCCCP and the State Council. 2002. "Guanyu zuohao 2002 nian nongye he nongcun gongzuo de jueding" (Opinion on properly carrying out the agricultural and rural work in 2002). Yunnan Zhengbao 2, 1-5.

Chang, Hongxiao. 2003. "Zhongguo nongcun 'fei gai shui' baogao" (Report on "tax-for-fee" reform in rural China). Nongcun gongzuo tongxun 7, 12-16.

Chen, Guidi, and Tao Chun. 2004. Zhongguo nongmin diaocha (Investigation on Chinese Farmers). Beijing: Renmin wenxue chubanshe.

Chen, Xiwen. 1992. "Jiushi niandai nongcun gaige yu fazhan mianlin de xin wenti" (New problems in the rural development and reform in 1990s). Zhongguo nongcun jingji 5, 3-10.

Chung, Jae Ho. 2000. Central Control and Local Discretion in China: Leadership and Implementation during Post-Mao Decollectivization. New York: Oxford University Press.

$\mathrm{Du}$, Dengshan, and Jianfeng Liu. 2001. "He Kaiyin xishuo 'er ci dabaogan"' (Interview with $\mathrm{He}$ Kaiyin on 'the second rural household contracting'). Zhongguo jingji shibao, 23 February.

Duckett, Jane, and Guohui Wang. 2017. "Why do authoritarian regimes provide public goods? Policy communities, external shocks and ideas in China's rural social policy making." Europe Asia Studies 69(1), 92-109.

Guojia shuiwu zongju nongshuiju keti zu (Research Group of Rural Tax Division, State Administration of Taxation). 2000. "Nongmin fudan yu nongyeshui gaige wenti" (Farmers' burden and the issue of agricultural taxation system reform). Shuiwu yanjiu 4, 22-32.

He, Kaiyin. 1995. "Shenhua nongcun gaige de you yizhang 'wangpai': Anhui sheng Taihe xian gaige nongye shuifei zhengshou banfa de diaocha" (Another "trump card" in deepening rural reform: investigation on rural tax and fee reform in Taihe county, Anhui province). Anhui juece zixun 9, 14-15.

Heilmann, Sebastian. 2008. "Policy experimentation in China's economic rise." Studies in Comparative International Development 43, 1-26.

Huang, Yasheng. 2008. Capitalism with Chinese Characteristics: Entrepreneurship and the State. Cambridge: Cambridge University Press. 
Jiang, Zemin. 1998. "Quanmian tuijin nongcun gaige, kaichuang woguo nongye he nongcun gongzuo xin jumian: zai Anhui kaocha gongzuo shi de jianghua” (Promoting rural reform in an all-around way and opening up a new situation of our country's agricultural and rural work: speech when inspecting the work in Anhui). Nongcun hezuo jingyi jingying guanli 11, 3-6.

Jiang, Zemin. 2002. "Quanmian jianshe xiaokang shehui, kaichuang zhongguo tese shehui zhuyi shiye xinjumian: zai Zhongguo gongchandang di shiliu ci quanguo daibiao dahui shang de baogao" (Building a well-off society in an all-round way and creating a new situation in the cause of socialism with Chinese characteristics: Report at the 18th National Congress of the CCP). Qiushi 22, 3-19.

Kennedy, John James. 2007. "From the tax-for-fee reform to the abolition of agricultural taxes: the impact on township governments in north-west China." The China Quarterly 189, 43-59.

Li, Lihui. 2005. "22 ge sheng shi qu mianzheng nongyeshui: wu nian quxiao nongyeshui youwang tiqian shixian" (Twenty-two provinces abolished agricultural tax: abolishing agricultural tax in five years will be realized ahead of schedule). Renmin ribao, 18 January.

Li, Linda Chelan. 2006a. "Differentiated actors: central-local politics in China's rural tax reforms." Modern Asian Studies 40(1), 151-174.

Li, Linda Chelan. 2006b. "Embedded institutionalization: sustaining rural tax reform in China." The Pacific Review 19(1), 63-84.

Li, Linda Chelan. 2006c. "Working for the peasants? Strategic interactions and unintended consequences in the Chinese rural tax reform." The China Journal 57, 90-106.

Li, Xiangang. 1995. "Guanyu nongcun shuifei zhidu gaige de diaocha yu sikao (Investigation and reflection on the reform of rural tax and fee system)." Nongye jngji wenti 7, 35-39.

Li, Zhilan, and Licai Wu. 2005. "'Daobi' haishi 'fandaobi': nongcun shuifei gaige qianhou zhongyang yu difang zhijian de hudong" (Pressure for changes: central-local interactions in rural tax-for-fee reform). Shehuixue yanjiu 4, 44-63.

Liu, Jianfeng, and Dengshan Du. 2002. "Shuifei gaige mengya jishi" (Report of the initiation of the rural tax and fee reform). Jianghuai wenshi 1, 4-13.

Liu, Mingguo. 2003. "Nongcun shuifei gaige yiran renzhong daoyuan: fang zhongnongban yuanzhuren, guowuyuan xibukaifa bangongshi fu zhuren Duan Yingbi" (Rural tax and fee reform still has a long way to go: interview with Duan Yingbi, former director of the Office of the Central Rural Work Leading Group and former deputy director of the Office of Developing the West of the State Council). Nongcun gongzuo tongxun 7, 7-9.

Ma, Mingye. 1995. "Anhui sheng Taihe xian nongye shuifei gaige de diaocha yu sikao" (Investigation and reflection on rural tax and fee reform in Taihe county, Anhui province). Zhongguo nongcun jingji 6, 45-47.

Mei, Ciqi, and Zhilin Liu. 2013. "Experiment-based policy making or conscious policy design? The case of urban housing reform in china." Policy Sciences 47(3), 321-337.

Nongcun zonghe gaige bangongshi (The Office of Rural Comprehensive Reform). 2008. "Woguo nongcun gaige de xin pianzhang: nongcun shuifei gaige he nongcun zonghe gaige huigu yu sikao" (New chapter for our country's rural reform: retrospection and reflection of rural tax and fee reform and rural comprehensive reform). Yusuan guanli yu kuaiji 7, 12-15.

Pan, Xiaoping. 2008. "Yibu kuaguo liangqian nian: Anhui nongcun shuifei gaige shimo" (Crossing two thousand years by one step: the whole story of the rural tax and fee reform in Anhui). Dangshi zonglan 11, 24-30.

Pang, Qinghui. 2012. "Jianmian nongye shui juece neimu" (The inside story of reducing and abolishing rural taxes), Zhongguo xinwen zhoukan, 19 November, 25-28.

Qi, Yiming. 2009. "Gaige kaifang yilai kuoda neixu zhanlüe fangzhen de xingcheng he fazhan" (The formation and development of the strategy of expanding domestic demand since the Reform and Opening-up). Dang de wenxian 4, 34-41.

State Council. 2001. "Guowuyuan guanyu jinyibu zuohao nongcun shuifei gaige shidian gongzuo de tongzhi" (Notice on further improving the work of rural tax and fee reform). Zhonghua renmin gongheguo guowuyuan gongbao 15, 9-13. 
Sun, Jie. 2003. "Quanmian jianshe xiaokang, zhongdian zai nongcun" (The countryside is the emphasis for building a well-off society in an all-round way). Xinhua meiri dianxun, 9 January.

Tsai, Wen-Hsuan, and Nicola Dean. 2014. "Experimentation under hierarchy in local conditions: cases of political reform in Guangdong and Sichuan, China." The China Quarterly 218, 339-358.

Wang, Shaoguang 2008. "Learning and adapting: the case of rural healthcare financing in China (Xuexi jizhi yu shiying nengli: Zhongguo nongcun hezuo yiliao tizhi bianqian de qishi)." Zhongguo shehui kexue 6, 111-13.

Wang, Xuefeng, Shugui Wang and Jie Zhang. 2001. "Nongcun shuifei gaige diyi ren: Ji Anhui sheng renmin zhengfu canshi He Kaiyin" (The first person of rural tax and fee reform: the counsellor of Anhui provincial government He Kaiyin). Zhongzhou shenji 8, 6-8.

Wen, Jiabao. 2003. "Wen Jiabao zongli da zhongwai jizhe wen: Zai dishi jie quanguo renmin daibiao dahui diyi ci huiyi juxing de jizhe zhaodaihui shang" (Premier Wen Jiabao answers questions of domestic and international journalists at the press conference of the First Session of the Tenth National People's Congress). Zhonghua renmin gongheguo guowuyuan gongbao 11, 25-30.

Wen, Jiabao. 2004. "Zhengfu gongzuo baogao" (Government Work Report), Renmin ribao, 17 March.

Wen, Tiejun. 2012. Baci weiji: Zhongguo de zhenshi jingyan 1949-2009 (Eight Crises: Lessons from China). Beijing: Dongfang chubanshe.

Xiang, Huaicheng. 2011. "Nongcun shuifei gaige shi zhounian jinian" (In memory of the tenth anniversary of the rural tax and fee reform). Renmin Luntan 3, 12-13.

Xiao, Jie. 2011. "Yichang zhongjiele 2600 nian 'huangliang' lishi de gaige" (The reform that terminated the 2,600-year history of tax payment to the emperor). Zhongguo caizheng 17, 8-15.

Yep, Ray. 2004. "Can 'tax-for-fee' reform reduce rural tension in China? The process, progress and limitations." The China Quarterly 177, 42-70.

Yep, Ray. 2008. "Enhancing the redistributive capacity of the Chinese state? Impact of fiscal reforms on county finance." The Pacific Review 21(2), 231-255.

Zhang, Qingsong. 2000. "Yiyi shenyuan de gaige: Anhui sheng shixing nongcun shuifei gaige de tansuo yu shijian" (The reform with profound meaning: Explorations and practices of the rural tax and fee reform in Anhui province). Zhonguo gaige 6, 8-12.

Zhao, Changbao. 1995. "Quanguo nongcun jiceng shuifei gaige jingyan yantaohui jiyao" (Summary of the nationwide rural grassroots tax and fee reform conference). Jingjixue dongtai 8, 34-37.

Zhu, Rongji. 2011. Zhu Rongji jianghua shilu (Zhu Rongji on the Record). Beijing: Renmin chubanshe. 